\title{
Diamox の抗病攣効果に関与る研究
}

\author{
第 2 編 \\ Diamoxの脳鹃遊離ア三ノ絰素に及卧す影響
}

岡山大学医学部第 1 (陣内) 外科数室（指尊：陣内呚授）

副手河原 佳正

〔昭和 33 年 2 月 6 日受稿〕

\section{第 1 草楮言ならひに文献}

従来，脳邻直アミノ酸は神経組織の代謝と機能，と

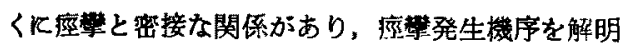
する鍵となろうとまでわれているものの，現在な 拉幾多の不明な点が残されている。

クルタミン酸（以下ク酸と略記する）山脳新陳代 貄関与する唯一のアミノ酸である之同時に, 脳路 で分解される唯一のアミノ酸であある1。

Weil-Malherbe は諸実験の結果, ク酸及びクルタ ミンは脳内酸化と酪酸形成に重要な役割をなし，ま た同時に脳随内でグ酸及びクルタミンの合成がおこ なわれる2). Krebs, Weil-Marherbe 等化よれば,

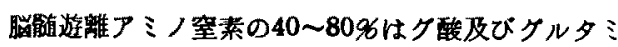

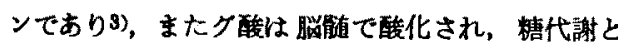
密接な関係があり、さらに Weil-Marherbe のいう どくく、アンモニア处理作用を有し，神経細胞のエ ネルギー源となり，醋酸系アセチールコリン合成に 関与し，神経細胞膜の透過度に影響してカリウム1 オンの喪失を防ぐ倬きがある゙)。

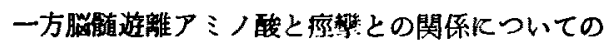
研究はいまだ少数の報告を散見するのみである，林 及びその門下6)は，動物実験でク酸ソータ、アスパ ラギン酸ソーダを皮質運動領に注射すれば厚綵が起 ることを埌告し， Richter \& Dawson6) によれば 应繁の直前より度繁後にかけて脸のアンモニアは增 加し, その含量が $9 \mathrm{mg}$ タとなつたときに摩繁が起 るという.これに対して中, 宗本7はク酸は脳骮ア

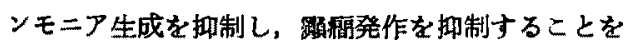
埌告した，これは脳内でグ酸がクルタミンとなりア ンモニアを吸收するためであるとし，一方ではアン モニアは畄内でクルタミンとなりらるがその後はど ろなるか不明であのという. Krebs8) も脑組織内人
はク醂及びアンモニアよりクルタミンを合成するに 必要なる䣼が含まれているとのへている。 Wael-

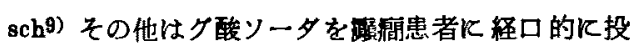
与すると，その小発作が著明別制せられるという. Sapirstein 10) はアンモニア投与による䂧墇発生をク

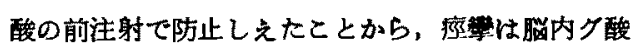

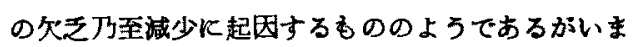
だ不明の点が多いと確答をさけている.

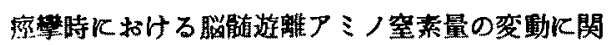
する報告をみると，井上11冲真正露蕑患者脳また潜 在性脸局所「アナフィラキン一」家兔脳（以下脳局 「ア」家兔脳と略記する）飞遊離アミノ窒菜の減少 を認め、Haber 及びSaidel12) は国を使用して「スト

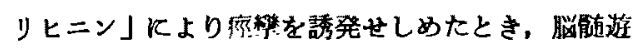
踓アミノ窒素量が正常鼠脸のそれK比し約30\%の減 少をみたという。和田13)は「ヘーパークロマトグラ フ」法て虐警重皘㭙飞脳内グ酸を中心とする各遊離 アミノ酸の诚少をみたという.高木14)はカルデアン゙

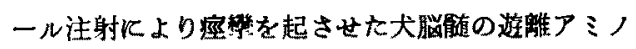

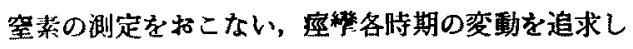

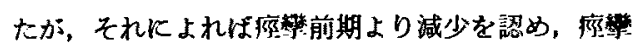

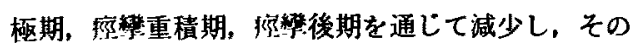
変動はレンズ核に著明であると埌告した。友沢15)も

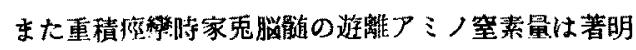
に減少することをのへ，先人はいずれも应然前期あ

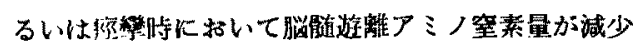
するという点で一致した報告をのべている.

他方江副16)に上れば。抗应㢣剂である Phenobarbital, Barbital 招よび Aleviatin は， 10-4 10-6 M. L の低港度では in vitro K括いてク酸脱水菜醉

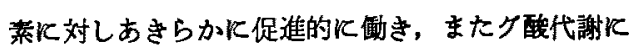
関係のある焦性フドー酸々化系, Acethylcholine 合成系を促進し，高洤度では排制するという。 
私は第 1 編飞执いて，Diamox の抗应禁効果をし らベ，その効果が脑水分の帨水によるものであると とを立証したのであるが，前述のごとく脸水分とと

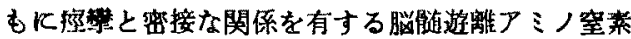
に対しては，Diamox がいかなる影響を与えるもの であるか、それを追求することも興味あることと考 えて本実験を試みた次第である.

な招高木14)の埌告飞もとずき，脳随遊離アミノ窒 素量の変動が著明にみとめられるという点及び比較 的多量に材料をえられるという点から检查部位とし て大脸皮澌を選んだ.

\section{第2章実略方法}

\section{第 1 節 実験動物}

実験動物としては一定期間（5７日間）同一食 躬で飼青せる体重 $2 \sim 4 \mathrm{~kg}$ の成熟猫を性別を考虑せ す使用した。

第 2 筑 Diamox の使用量及び使用方法

Diamox 注射波（pH 8.4 8.8 であるDiamox Natron 等量混合波）在作阷 し，当 pro $\mathrm{kg} 30 \mathrm{mg}$ を後脚筋内内に注射した。

第 3 第 腷随埰取封期

第 1 編脳含水量の実験成績《ならい, 正常㭙上注 射後 9 時間及び24封間とした.

第 4 笛脳剔出手技

すで第 1 編でのべたごとくである。

第 5 管 抽出旅作製法

脳剔出後凝血と脳䡉膜老除去して大敛皮質のみを とり，正確に秤量して蓋付瓶中下入れ，硫酸々性純 アルコール(コンゴロート試験紙)10ec を添加して72 封間氷室内反保存する，これは後述の脱脂及び除蛋 白を容易炕するためである，72時間後に取出し，虍 紙で紨アルコールを清拭し，乳錸内に移して倍量の 石油エーテル（洮点 $40^{\circ} \mathrm{C}$ 以下）之混合磨确する. ついで石油エーテルを注加して蓋付瓶中に入れ室温 飞放置し，24㭙間後3000回転15分閶遠沈を行い，石 油エーテルを更新する。この操作を24㭙間每に 3 回 反復して脱脂を括わり，ついで10倍量の蒸溜水を添 加， $40^{\circ} \mathrm{C} ， 1$ 㭙間重滑塑中で筧拌しつつ抽出を行

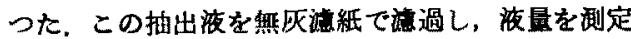
して打いた，この被液 $5 \mathrm{cc} 飞 0.6 \% \mathrm{KH}_{2} \mathrm{PO}_{4} 5 \mathrm{cc}$, 10\% Squibb 紫尿素分解醉菜溶液 $0.1 \mathrm{cc}$ を加之， 粰卵器内に30分間放置する. かくして潗液中の尿菜 は分解される。 さらK Folin-Wu 変法て除蛋白を行

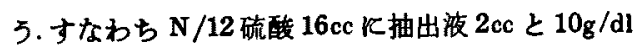

タンケステン酸ソータ溶液 $2 \mathrm{cc}$ を加え，充分飞振

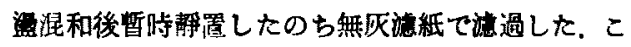
の溶液を浭質コルペンにとり，水酸化マグネンウム 浮遊液数䙘を滴下，5 10 分間者沸して容植を半減 せしめる。ついで水醋酸を滴下すると液は酸性とな り水酸化マグネンウムが溶解するにいたる，硬質コ ルペンは蒸溜水少量にて洗い，はじめの容稙となる よろにした，游蜼アミ/窒素の定量にはこの液 $5 \mathrm{co}$ を使用した。

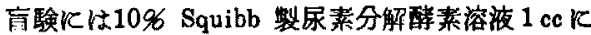
$10 \mathrm{~g} / \mathrm{d} 1$ タンクステン䣹ソー夕溶液 $0.5 \mathrm{cc}$ 及び $\mathrm{N} / 12$ 硫酸 $4 \mathrm{cc}$ を加光，10 cc となるよ弓蒸溜水て稀粐し，

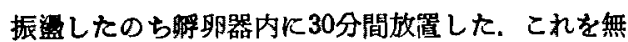

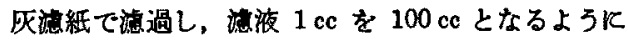
稀积した。 この液 $5 \mathrm{cc}$ をむちいて盲験を行つた。

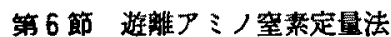

定偂はVan-Slyke のガス検仕法17によより括こな つた，すなわち藤井18)，赤䏱(9)，藤田201の記載を参 考化し、Van-Slyke \& Neil あ装置をるらい, 抽出

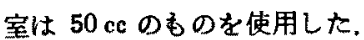

試薬.

1）無硝酸ソー夕液は $1 l$ の水に $\mathrm{NaNO}_{2} 800 \mathrm{~g}$ を加温溶解。

2）水醋醂.

3）アルカリ性過マンガン酸カリ波は. 11 の10\% $\mathrm{NaOH}$ K $50 \mathrm{~g} の \mathrm{KMnO}_{4}$ を飽和せしぬる。この液 は毎回新作彆し，使用前室温飞放置して空気に飽 和せしめる。

4）カプリールアルコール

測定飞怯滤液 $5 \mathrm{cc}$ を抽出室に入れ，水醋酸 $1 \mathrm{cc}$ を数回洗込み，カプリールアルコール1滴を加え て泡涞の発生を防いだ，抽出室を真空にして 1 分間 200 300回で 2 分間振㵝し，その際抽出された空気 を排出せしめる。ついで 2 ce の亜硝酸ソー夕溶液 を室内に注入するとただちに N2 カス及び NO カス か発生する．水銀面を抽出室の $50 \mathrm{cc}$ 目盛附近飞ま で下げ，この将の反応温度火応じて所定の㭙間放置

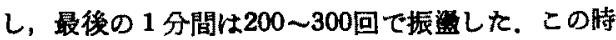
発生したカスを Hempel-pipette 内化移行せしめ, Pipette 内のアルカリ性過マンカンン酸カり洨と混和 せしめ NO カスを吸收， N2 カスのみを再び抽出室 内に返した。水鋥面を所定の標線まで下けて $\mathrm{N}_{2}$ カ スの压を测定し，計算により脸骮道新鮮重量 $1 \mathrm{~g}$ 中の 遊離アミノ窒量 $(\mathrm{mg})$ 亿換算した。

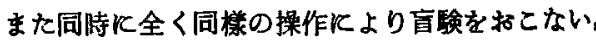


亜硝酸ソータ溶液及び尿菜分解䤃素溶液火より生ず

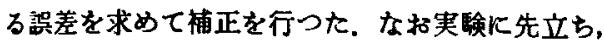
クリンン $0.1 \mathrm{~g}$ を蒸燃水 $50 \mathrm{cc} \mathrm{K}$ 溶解し，その $2 \mathrm{cc}$ を本操作により定鼠して計算值 $(0.7466 \mathrm{mg})$ と一 致することをたしかめた。

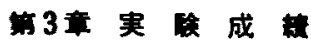

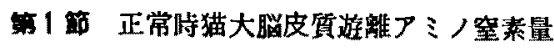
8 例の猫につき洣定した正常時猫大脸皮犋の遊誰 アミノ窒素星を，新鮮重量 $1 \mathrm{~g}$ 換算值で示せば，第 1 表及び第 1 図のごとくである。すなかち，最高 $0.6076 \mathrm{mg} / \mathrm{g}$ ，最低 $0.4978 \mathrm{mg} / \mathrm{g}$ ，標㩐偏差 0.0379 て，平均 $0.5513 \mathrm{mg} / \mathrm{g}$ であつた.

第 1 区 猫大脑皮質遊離〉ミノ窒菜昷

$$
\text { (単位…...mg) }
$$

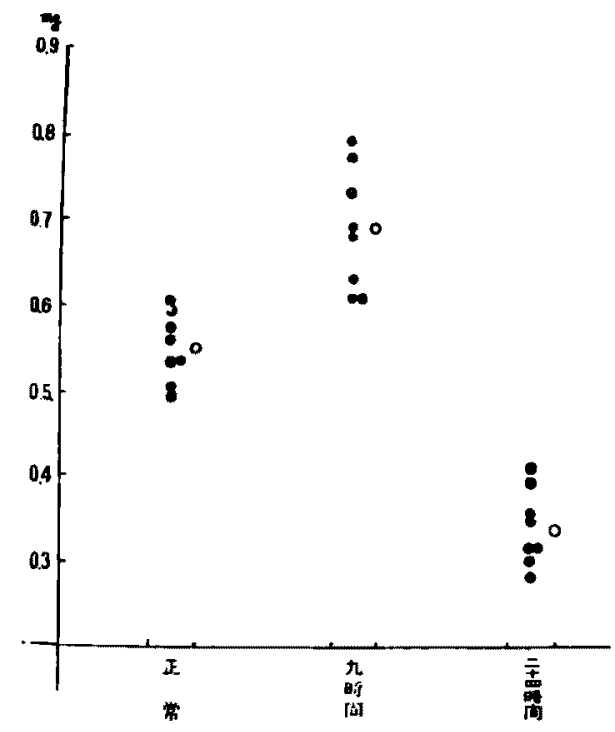

第 2 笛 注射後 9 時間群

Diamox 注射後 9 時間で測定した 8 例の猫大敛皮

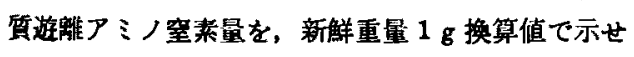
注，第 1 表及び第 1 圀のごとくである。

すなわち、最高 $0.7975 \mathrm{mg} / \mathrm{g}$, 最低 $0.6141 \mathrm{mg} / \mathrm{g}$, 標準编差 0.0713 で，平均 $0.6941 \mathrm{mg} / \mathrm{g}$ であり，そ れを正常畤と比较すれば25.996の增加を認めた。

第 3 第 注射後24牌間群

Diamox 注射後24時間で則定した 8 例の猫大畄皮 質遊離アミノ窒菜量を, 新鮮重量 $1 \mathrm{~g}$ 換算值で示せ け，第1表及び第 1 困のごとくである.

すなわち、最高 $0.3987 \mathrm{mg} / \mathrm{g}$, 最低 $0.2848 \mathrm{mg} / \mathrm{g}$, 標染偏差 0.0427 で，平均 $0.3456 \mathrm{mg} / \mathrm{g}$ であり，こ
第 1 表 猫大脳皮質遊離アミノ窒素

\begin{tabular}{|c|c|c|c|}
\hline \multicolumn{4}{|c|}{ 単位……mg } \\
\hline 实糇番号 & $\begin{array}{l}\text { 主射後断頭 } \\
\text { 迄の眝間 }\end{array}$ & $\begin{array}{l}\text { 避離 } \\
\text { 美 }\end{array}$ & 增加率 \\
\hline 1 & \multirow{8}{*}{ 正常 } & 0.5765 & \\
\hline 2 & & 0.5383 & \\
\hline 3 & & 0.5949 & \\
\hline 4 & & 0.4978 & \\
\hline 5 & & 0.6076 & \\
\hline 6 & & 0.5601 & \\
\hline 7 & & 0.5032 & \\
\hline 8 & & 0.5317 & \\
\hline 平均 & & 0.5513 & \\
\hline 標染偏差 & & 0.0379 & \\
\hline 增加率 & & & $0 \mathscr{6}$ \\
\hline 9 & \multirow{8}{*}{9 時間 } & 0.7777 & \\
\hline 10 & & 0.6907 & \\
\hline 11 & & 0.7388 & \\
\hline 12 & & 0.6333 & \\
\hline 13 & & 0.6141 & \\
\hline 14 & & 0.7975 & \\
\hline 15 & & 0.6171 & \\
\hline 16 & & 0.6836 & \\
\hline 平均 & & 0.6941 & \\
\hline 標準偏差 & & 0.0713 & \\
\hline 增加率 & & & $25.9 \%$ \\
\hline 17 & \multirow{8}{*}{24 時 間 } & 0.3058 & \\
\hline 18 & & 0.3228 & \\
\hline 19 & & 0.3228 & \\
\hline 20 & & 0.3608 & \\
\hline 21 & & 0.4177 & \\
\hline 22 & & 0.3513 & \\
\hline 23 & & 0.2848 & \\
\hline 24 & & 0.3987 & \\
\hline 平均 & & 0.3456 & \\
\hline 摽準偳差 & & 0.0427 & \\
\hline 增加率 & & & $-37.3 \%$ \\
\hline
\end{tabular}

れを正常時と比较すれば37.3\%の減少を認めた。

\section{第4章栝括ならひに考按}

すでのの゙たことく，㜆随逰離アミノ窒素の40〜

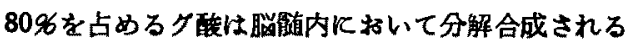
唯一のアミノ酸であり，主な作用をのべればアンモ 
二ア处理作用とAch 合成と火関与し，神経細胞膜 の透過度飞も影響をあた克るといわれている。

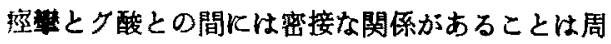
知の事実であり，一般に疗䇣はク酸の減少乃至は消 失に起因するもののごとくであって，これを裏づけ る研究が報告されている910》。

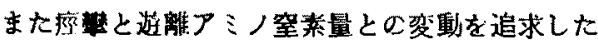

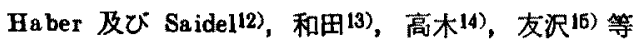

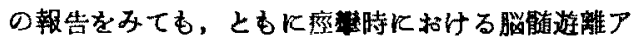

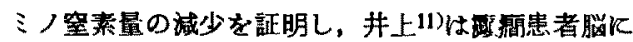
招いてもその減少を認めている。一方畠山21)は，慢 性脸局「ア」家兔脳観の遊離アミノ窒素量が減少し ている事実は，疗拿誘発による後天的変化を除外し， かつ無処置期間が長期となつても遊離アミノ窒素量 の减少が正常飞復さない点から，この減少は应熬誘

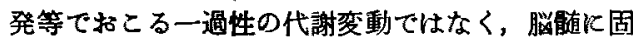
定した異常代謝であろうと推測している．以上のご とくク酸の娍少が源謷を誘発することは多くの報告 が物語つているところである.

他方，中・宗本7) はグ酸の㾞発作抑制作用か脸 野アンモニア生成の抑制飞よるあのであるとのへ，

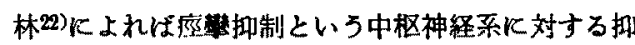
制の本热は， $\boldsymbol{\gamma}$-アミノ $\boldsymbol{\beta}$-オキン酪酸によるもので ありそそのものは生体内でク醂から作られるとい 亏.

江副16)は抗应㢣剂である Phenobarbita1, Barbital 及び Aleviatin はグ酸脱水菜醉素の作用を促進，と

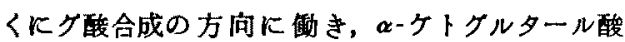
$+\mathrm{NH}_{3} \rightarrow$ ク䣹の方向に進み， $\mathrm{NH}_{3}$ 除去の作用があ ると考えている.

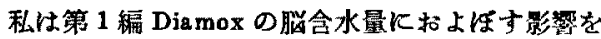

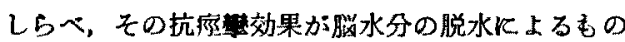
であることを証明したのであるが，さらに Diamox

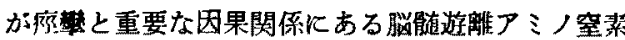
に対しては，いかなる影響をあたえるものであるか をうかがい知るために本寒験を試みた次第である。

ここで私の寒験成綪をのべる.

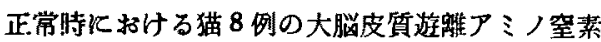
舀は，平均 $0.5513 \pm 0.0379 \mathrm{mg} / \mathrm{g}$ であつた。従来

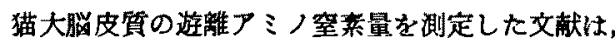
見当らないようである。しかしながら猫全脳のアミ ノ酸を定量した Tallan et al.23)，猫及び鼠畄では ク酸やクルタミンの量にはとんど大差を認めないと い5 Weil-Malherbe2A)，さらK灰白質と白質とでは ク酸及びクルタミンの量が前者がより高い值を示す
そいう Krebs et al. 24) 諸報告から推定すれげ， 大略 $0.5 \mathrm{mg} / \mathrm{g}$ よりさら飞高い値をとるすのと考元 られる.したがつて私の実験值は誤りないむのと思 われる。

ついで Diamox 注射後 9 時間飞标ける猫 8 例の 平均值は $0.6941 \pm 0.0713 \mathrm{mg} / \mathrm{g}$ となり, 正常㭙伿 比し25.9\%に及ぶ增加を認めた。

さらに Diamox 注射後 24 時間值をみるK，平均 $0.3456 \pm 0.04727 \mathrm{mg} / \mathrm{g}$ で, 正常值と比較すれば逆 に 37.3 名の減少をみた。

このよろに Diamoxの投与は，大脳皮質の遊離ア ミノ窒素量を增加させることを認めた。 この事実と 抗座效果との関係孝推察するに，遊離アミノ窒索 の増量はすなわちク酸及びタルタミンの増量であり， 脸内ク酸及びクルタミンの増量によつて畄内アンモ ニアの处理が促進され，上つて抗庭靽効果をるら するのと考光られるが，このととは中・宗本7， Waelsch ${ }^{9}$, Sapirstein 10), 江副(6) ならびそ林22)の 諸報告からみても容易にうなずけることである。な 打注射後 24 時間で正常值以下減少したことは， Diamox の抗与により脳内グ酸及びクルタミン合成 があまりにす旺盛に括となわれるために，その合成 源の不足をきたし，Diamox の效力減退ととも飞次 第に減少火㑯き，24㭙間で正常狀態復帰しえず， 正常值以下の值をとるにいたるものと考学られる.

\section{第 5 章 結論}

猫に Diamox 老投与し，猫大脳皮質の遊離アミ ノ等絜量を測定した。

1）正常猫大脳皮質の遊離アミノ窒䒺是は，西均 $0.5513 \pm 0.0379 \mathrm{mg} / \mathrm{g}$ である。

2) Diamox 注射後 9 㭙間群炕招ける值は，平均 $0.6941 \pm 0.0713 \mathrm{mg} / \mathrm{g} て ゙$ ，これを正常時と比較すれ ば25.9\%の増加を示した。

3） Diamox 注射後24㭙間群に怙ける做は，平均

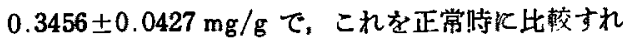
ば37.3\%の减少を示した.

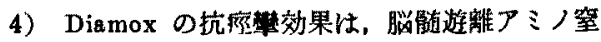

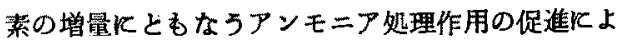
るものと考元られる。

擱筆するに当り，終始御㤵篤なる御指導と御校閲 を睗つた恩仰陣内教授に深甚なる感謝の意を表す ろ. 
交献

1) Price, Waelseh and Putnam: 市川政: 且新 医学, 36, 394 400 (1949) より引用.

2) H. Weil Marherbe: Biol. J. 30, 669 676 (1936)

3) H. Weil Marherbe: Physiol. Review, 30 , $549 \sim 568$ (1950)

4) H. Weil Marherbe: Physiol. Review, 30, $549 \sim 568$ (1950)

5) 林: 生理学講坐, 10, II, 12, 36 (1951), 兼 松：岡山医学会 雑誌，65, 1287〜1292， S 28 より引用.

6) Richter \& Dawson: Physiological Reviews, 30５49 568 (1950) 上り引用.

7) 中：生体の科学, 4, 106 112（1952）

8) H. A. Krebs: Bioch J. 29, $1951 \sim 1969$ (1935)

9) H. Waelsch, J. C. Price \& T. J. Putnam : J. A. M. A., 122, 1153 1160 (1943)

10) R. M. Sapirstein: Proc. Soci. Exper. Biol. Med. 52, 334 (1943), 高木 岡山医学会雑誌, 65, 1113 1125, S 28 より引用.

11）井上：岡山医学会雑誌，64，1637～1646（1952）
12) C. Haber, L. Saidel: Federat. Proceed, 7. 1 (1948), 高木 : 岡山医学会雑誌, 65, 1113 1125, s 28より引用.

13）和田：精神々経学雜誌，53，20２1，（1951）

14) 高木：岡山医学会雜誌，65，1113～1125（昭28）

15）友沢 周山医学会雑誌，68，935 943， S 31 .

16）江副：精神々経学雜誌，54，510５11（1952）

17) D. D. Van Slyke: J. Biol. Chem. 16, 231 233 (1913)

18）藤井：生化学実験法（定量穊）78-81（1947）

19）赤堀， アミ，酸及蛋白質，176１86（1946）

20）藤田：检王法之其空用，472４81（S. 24）

21）皂山：岡山医学会雜誌，68，525５31（S. 31）

22）林：診断と治撩，44，1４，（S. 31）

23) H. H. Tallan, S. Moore and W. H. Stein : J. Biol. Chem. 211, 927 939 (1954)

24) Weil. Malherbe: Physiol. Rev. 30, 549 568 (1950)

25) Krebs, H. A., Eggleston, L. V. and Hems, R. : Biochem, J. 44, 159 162 (1949)

\title{
Studies on the Anticonvulsive Effects of Diamox
}

Part II.

The Effects of Diamox on the Free Amino Nitrogen in the Brain.

By

\author{
Yoshimasa Kawahara \\ Dept. of Surgery, Okayama University Medical School \\ (Director: Prof. Dr. D. Jinnai)
}

The effects of Diamox on the free amino nitrogen in cats brain were measured

The experiments were performed by Van-Slyke method taking the samples at 9 and 24 house respectively after the injection of Diamox.

Concerning about the mean values of each 8 cases, the free aminonitrogen showed $25.9 \%$ increase at 9 hours, while $37.3 \%$ decrease at 24 house than the normal values.

The anticonvulsive effects of Diamox were considered to be based on the ammonium management accompanying with the increases of glutamic acid.

On the contrary, the decreases of the free amino nitrogen were considered to be based on the lack of the sources of glutamic acid synthesis. 